Original Article

\title{
DOSE-DEPENDENT PROTECTIVE FEATURES OF LOBOPHORA VARIEGATA METHANOLIC EXTRACT (LVME) IN N-NITROSODIETHYLAMINE INDUCED EXPERIMENTAL HEPATOCARCINOGENESIS IN RATS
}

\author{
ADAIKKALAM AJITHA ${ }^{1}$, PERUMAL SUBRAMANIAN ${ }^{*}$ \\ 1Department of Biochemistry and Biotechnology, Annamalai University, Chidambaram, Tamil Nadu, India \\ Email: psub@rediffmail.com
}

Received: 04 Aug 2021, Revised and Accepted: 10 Oct 2021

\begin{abstract}
Objective: This study explores the anti-cancer property of Lobophora variegata, also an effective dose to treat hepatocarcinoma in Male Albino Wistar rats in N-nitrosodiethylamine induced hepatocarcinoma paradigm and its possible mechanism of action.

Methods: In this study, rats were segregated into five groups; group-1 (control), group-2 treated with 0.01\% NDEA through drinking water for 15 w, group-3 NDEA+treated with Lobophora variegata methanolic extract (LVME) (100 mg/kg b.w.), group-4 NDEA+treated with (LVME) (200 mg/kg b.w.) and group-5 NDEA+treated with (LVME) (400 mg/kg b.w.).

Results: After the experimental period, functional and morphological changes in the liver were observed both macro and microscopically, the activities of liver marker enzymes, alkaline phosphatase (ALP), aspartate and alanine transaminases (AST and ALT) were analyzed. Administration of LVME as $200 \mathrm{mg} / \mathrm{kg}$ b.w. (to NDEA treated rats) significantly (i) reduced the preneoplastic lesions alleviated lipid peroxidation through scavenging free radicals, (ii) enhanced antioxidant status and reverted liver/disease marker enzymes plausibly by modulating xenobiotics
\end{abstract} metabolizing enzymes (XMEs) and by exhibiting antiproliferative and cytoprotective effects.

Conclusion: LVME doses higher than $200 \mathrm{mg} / \mathrm{kg}$ b.w. are not effective in quenching the free radicals and restoring the liver functions as saturation level could have been reached; also, doses lower than $200 \mathrm{mg} / \mathrm{kg}$ b.w. could not be effective as they are below the optimum dose required to exhibit the pharmacological effects.

Keywords: Free radicals, Hepatocarcinoma, Lobophora variegate, N-nitrosodiethylamine Xenobiotic enzymes

(C) 2021 The Authors. Published by Innovare Academic Sciences Pvt Ltd. This is an open-access article under the CC BY license (https://creativecommons.org/licenses/by/4.0/) DOI: https://dx.doi.org/10.22159/ijcpr.2021v13i6.1920 Journal homepage: https://innovareacademics.in/journals/index.php/ijcpr

\section{INTRODUCTION}

Liver cancer a most common malignancy worldwide. According to the 2018 Global Cancer Statistics, it ranks 7th and 3rd among all cancers in terms of worldwide incidence and mortality, correspondingly. Around 850,000 new cases of liver cancer and 770,000 related deaths were recorded per annum recently [1]. HCC arises owing to various biological processes, for instance, viral hepatitis, cirrhosis, toxin exposure, which directly affect the liver tissue [2]. N-Nitrosodiethylamine (NDEA), a dialkyl nitrosoamine is a strong hepatocarcinogen that exists in tobacco smoke, contaminated water, cheddar cheese, curd, fried foods and in most of the alcoholic beverages. N-Nitrosodiethylamine is reported to inhibit most the nuclear enzymes involved in DNA repair/replication and thus could cause hepatocellular carcinoma (HCC) after administration in experimental animals [3]. Nitrosamines are classified as an important class of carcinogens posing a substantial hazard to human well-being [4,5]. Elevated concentrations of NDEA ranging from $4.8 \mu \mathrm{g} / \mathrm{kg}$ are present in maize bread and $10-20 \mu \mathrm{g} / \mathrm{kg}$ in sausage, fish and milk products [6]. DEA causes cellular damage and redox imbalance, which is a state caused by production of excessive of reactive oxygen species (ROS) and inequality in the ratio of free radicals to antioxidants [7]. Reactive oxygen species (ROS) are toxic byproducts of cell metabolism which distress the growth and development of the cell and ultimately causes its death, also the free radicals synthesized by cytochrome P-450 mono oxidase system elevate oxidative stress by the synthesis of superoxide anions and $\mathrm{H}_{2} \mathrm{O}_{2}$ [8]. As the liver is the major site for metabolic biotransformation of NDEA, the synthesis of ROS can cause oxidative stress, leading to damage to the liver [9]. These ethyl radicals produced by NDEA and other reactive radicals interact with DNA causing mutations, elevation in blood markers such as aspartate transaminase and alanine transaminase (AST and ALT), decrement in antioxidants such as glutathione-S-transferase (GST), catalase (CAT), superoxide dismutase (SOD) and reduced glutathione (GSH) and ultimately resulting neoplastic transformation in liver tissue [10]. The aim of the current investigation is to assess the chemopreventive efficiency of the methanolic extract of Lobophora variegata (seaweed) (LVME) against NDEA-induced hepatocarcinogenesis in rats. Hepatocarcinogenesis was made by the administration of NDEA (through drinking water). The protective effect of LVME on NDEA-induced liver carcinoma in rats was evaluated by assessing the oxidative stress biomarkers, antioxidants (enzymatic and non-enzymatic) and liver markers. Although the chemotheraphy and immunization are the best ways available to treat and prevent HCC, respectively, an efficient way to overcome the limitations poised by the therapeutic agents like hemopoietic suppression, immunotoxicity, drug resistance, etc, is still elusive. It is in this context, evaluation of novel phytoextracts in the prevention of liver carcinoma is essential.

The marine algae (sea weeds) are rich natural resources of various biologically active compounds, for instance, polyunsaturated fatty acids (PUFAs), proteins, sterols, antioxidants, bioactive polysaccharides and pigments. They possess more than 65 trace elements at a noticeably higher concentration than terrestrial plants and they also contain protein, iodide, bromide, several vitamins, and substances of antibiotic nature [11]. As many seaweed algae live in habitats in extreme conditions and, as a consequence of in adaption to these adverse environmental surroundings, they synthesize a wide range of secondary metabolites having significant pharmacological properties [10-12], which cannot be found in other organisms. Lobophora variegata is a common brown alga that is widely distributed in shallow water ecosystems of tropical and subtropical areas, including coral reefs of the Carribean, the Indian Ocean, and the Red Sea. In coral reefs, Lobophora variegata is an abundant organism of the marine ecosystem and contains rich concentration of phenolic compounds chiefly bromophemols [12]. 
Secondary metabolites like phlorotannis are produced by the polymerization of phloroglucinol and they are abundantly present in marine brown algae, including Lobophora variegata, which are known to exhibit numerous biological activities such as, antidiabetic, anti-inflammatory, antimicrobial, antihypertensive and radioprotective properties [11]. Bioactive peptides are synthesized as a consequence of enzymatic hydrolysis in seaweeds [13]. These bioactive peptides predominantly have antimicrobial, antioxidant and anticoagulant properties and in addition, they play a key role in the amelioration of several cardiovascular diseases [14].

Free radicals are highly reactive chemical species with one or more unpaired electrons. These comprise oxy-radicals oxygen free radicals and several forms of them. Collectively, they are called as reactive oxygen species (ROS). Owing to the existence of one or more unpaired electrons, these species are paramagnetic and they are extremely reactive [15]. Because of the lone pair of electrons, free radicals can accept electrons from atoms or molecules, this reaction is called oxidation and free radicals are known as oxidants. Free radicals are proficient to react with nearly all known molecules of the biological system in their vicinity. Free radicals could damage proteins, initiate the breakdown of DNA duplex and cause the peroxidation of numerous biological molecules. Hence, nearly all the key components of cells are prone to be damaged by free radicals.

The phytochemical constituents of L. variegata, such as phenolics, tannins, glycosides, saponins, terpenoids, anthraquinones, flavonoids, and alkaloids play a vital role against pathogens [12] These compounds also have noteworthy potential as antioxidant, antitumor and anticoagulant properties due to their cytoprotective, anti-proliferative and other activities [16]. Brown algae or Phaeophyceae are the main sources of foucoxanthin since, the predominant pigment of brown seaweeds is fucoxanthin and gives the seaweeds brown colour. Fucoxanthin contains an allenic moiety and some other functional groups containing oxygen like epoxy, alcohol and ester. Further, carotenoids, polysaccharides, namely bioactive substances of brown seaweeds stop the uncontrolled division of blood cells [12]. It is observed that phlorotannins such as fucodipholoroethol $\mathrm{G}$ and phlorofucofuroeckol A of phlorotannins are active against allergic pathway on basophilic leukaemia cell lines [10-12]. As almost no comprehensive investigations have been made previously, we aimed to investigate the protective and dosedependent influences of L. variegata (methanolic extract) (LVME) in NDEA-stimulated hepatocarcinogenesis in rats.

\section{MATERIALS AND METHODS}

Adult male wistar rats $(\mathrm{n}=30 ; 120-140 \mathrm{~g})$ obtained from Central Animal House, Rajah Muthiah Medical College, Annamalai University, Annamalainagar, India, were used in the present study in five groups. The animals were housed in plastic under light: dark cycle (12:12), $50-60 \%$ humidity and at $25-27{ }^{\circ} \mathrm{C}$. They were provided with a standard pellet diet. The animals used in the present study were maintained as per the principles and guidelines of the Ethical Committee for Animal Care of Annamalai University in accordance with the Indian National Law on animal care and use. Ethical Proposal No: AU-IAEC/1204/4/18 dated 27-04-2018. alginates, laminarins, fucans, and cellulose, are present. The

\section{Preparation of Lobophora variegata methanolic extract (LVME)}

$5 \mathrm{~g}$ of Lobophora variegata powdered seaweed was extracted overnight with $100 \mathrm{ml}$ methanol at $32{ }^{\circ} \mathrm{C}$ and centrifuged at 2500 rpm for $15 \mathrm{~min}$. The supernatant was collected in a container after filtering through a filter paper and the residue was re-extracted four times under the same conditions. The collected extract was frozen dried and was kept at $80^{\circ} \mathrm{C}$ until further use. The dried extract was suspended in a required and minimum amount of water and used in the study.

\section{Chemicals and experimental induction of hepatocarcinogenesis}

$\mathrm{N}$-nitrosodiethylamine was procured from Sigma Chemical Co., St Louis, MO, USA. All other chemicals used in the study were of analytical grade. Hepatocellular carcinoma was induced in rats by treating with $0.01 \%$ NDEA through drinking water for $15 \mathrm{w}$ [11]. Lobophora variegata methanolic extract (LVME) was administered at the doses100,200, $400 \mathrm{mg} / \mathrm{kg}$ b.w. in distilled water weekly thrice orally for $15 \mathrm{w}$.

\section{Experimental design}

In this investigation, a total of 30 rats will be used. The animals were randomized and divided into 6 groups of 5 animals each. Group 1control, group 2-NDEA (0.01\%), group3-NDEA+LVME $(100 \mathrm{mg} / \mathrm{kg}$ b.w.), group 4-NDEA+LVME (200 mg/kg b.w.) and group 5NDEA+LVME (400 mg/kg b.w.)

\section{Histopathological studies}

The liver samples were fixed for $48 \mathrm{~h}$ in $10 \%$ formalin, dehydrated in ethyl alcohol-water mixture, washed in xylene and embedded in paraffin. Liver sections (5-6 $\mu$ m thick) were prepared, stained with hematoxylin and eosin dye (HandE) and mounted in a neutral DPX medium for microscopic examination.

\section{Biochemical investigations}

The assays of serum aspartate and alanine transaminases (AST and ALT) were performed by the method of Reitman and Frankel [17]. In liver tissue, levels of lipid peroxidation as evidenced by thiobarbituric acid reactive substances (TBARS) [18], and antioxidants (enzymatic as well as non-enzymatic), GSH [19] glutathione peroxidase (GPx) [20] and glutathione-S-transferase (GST) [21] were assayed.

\section{Statistical analysis}

All values were expressed as mean \pm SD. The statistical significance was evaluated by one-way of analysis of variance (ANOVA) using SPSS version 11.5 (SPSS, Cary, North Carolina, USA), and the individual comparison was done by Duncan's multiple range test (DMRT) and $p$ value $<0.05$ is considered significant.

\section{RESULTS}

Body and liver weights and activities of liver/stress marker enzymes

The liver and body weights of rats of all groups were shown (table 1).

Table 1: The liver and body weights of rats of all groups were

\begin{tabular}{|c|c|c|c|c|c|}
\hline Parameters with units & $\begin{array}{l}\text { Group } 1 \\
\text { control }\end{array}$ & $\begin{array}{l}\text { Group } 2 \\
\text { NDEA }\end{array}$ & $\begin{array}{l}\text { Group } 3 \text { NDEA+LVME } \\
(100 \mathrm{mg} / \mathrm{kg} \text { b.w.) }\end{array}$ & $\begin{array}{l}\text { Group } 4 \text { NDEA+LVME (200 } \\
\mathrm{mg} / \mathrm{kg} \text { b.w.) }\end{array}$ & $\begin{array}{l}\text { Group } 5 \text { NDEA+LVME } \\
(400 \mathrm{mg} / \mathrm{kg} \text { b.w.) }\end{array}$ \\
\hline Body weight final (g) & $145 \pm 15.21^{\mathrm{a}}$ & $125 \pm 10.33^{d}$ & $132 \pm 10.90^{\mathrm{b}}$ & $142 \pm 12.45^{\mathrm{a}}$ & $137 \pm 15.07 \mathrm{c}$ \\
\hline Liver weight(g) & $3.82 \pm 0.82^{\mathrm{a}}$ & $6.2 \pm 0.87^{b}$ & $5.17 \pm 1.21^{\mathrm{c}}$ & $3.91 \pm 0.96^{\mathrm{a}}$ & $4.1 \pm 1.06^{\mathrm{b}}$ \\
\hline Relative liver weight (g) & $2.71 \pm 0.07^{a}$ & $4.96 \pm 0.13^{\mathrm{b}}$ & $3.9 \pm 0.13^{c}$ & $2.74 \pm 0.11^{\mathrm{b}}$ & $2.9 \pm 0.10^{\mathrm{b}}$ \\
\hline AST (IU/l) & $53.12 \pm 2.96^{\mathrm{a}}$ & $107.52 \pm 11.52^{\mathrm{c}}$ & $64.37 \pm 4.62^{\mathrm{b}}$ & $56.42 \pm 3.20^{b}$ & $96.32 \pm 10.89^{a}$ \\
\hline ALT (IU/l) & $27.42 \pm 2.22^{\mathrm{a}}$ & $64.52 \pm 4.96^{\mathrm{b}}$ & $43.20 \pm 3.89^{c}$ & $29.81 \pm 3.72^{\mathrm{a}}$ & $52.87 \pm 3.18^{c}$ \\
\hline $\operatorname{ALP}(I U / 1)$ & $82.53 \pm 6.37^{a}$ & $171.27 \pm 13.36^{c}$ & $158.52 \pm 12.06^{b}$ & $85.79 \pm 5.81^{b}$ & $110.92 \pm 10.01^{\mathrm{a}}$ \\
\hline $\mathrm{LDH}$ & $105.51 \pm 2.13^{\mathrm{a}}$ & $158.63 \pm 13.22^{b}$ & $150.19 \pm 11.85^{\mathrm{c}}$ & $110.19 \pm 11.82^{\mathrm{a}}$ & $136.55 \pm 11.51^{\mathrm{c}}$ \\
\hline GGT & $0.65 \pm 0.02^{\mathrm{a}}$ & $0.97 \pm 0.06^{b}$ & $0.87 \pm 0.06^{b}$ & $0.69 \pm 0.02^{c}$ & $0.82 \pm 0.04^{\mathrm{a}}$ \\
\hline AFP & $7.95 \pm 0.14^{\mathrm{a}}$ & $40.82 \pm 2.36^{c}$ & $37.23 \pm 2.08^{\mathrm{d}}$ & $8.12 \pm 0.81^{\mathrm{a}}$ & $35.95 \pm 1.04 \mathrm{~b}$ \\
\hline
\end{tabular}

Values are means \pm SD from six rats in each group. Values not sharing a common superscript differ significantly at $p<0.05$ ANOVA followed by DMRT. 
The body weights were noticeably reduced in NDEA treated rats and NDEA+LVME (100 mg/kg b.w. and $400 \mathrm{mg} / \mathrm{kg}$ b.w.) as compared to controls. However, administration of LVME (200 mg/kg b.w.) to the group 4 rats was significantly decreased the relative liver weight as related to NDEA treated groups. NDEA-induced hepatocarcinogenesis caused atypical liver function in the experimental rats. Levels of serum liver-specific/disease marker enzymes such as AST, ALT, ALP, LDH, GGT and AFP were noticeably augmented $(\mathrm{p}<0.05)$ in NDEA treated animals as related to control animals. The treatment with
NDEA+LVME caused a decrement in ALT, ALP, LDH, GGT and AFP $(p<0.05)$. In group 4 , a tendency towards the normal level of enzymes has been observed ( $p>0.05$ ) when compared to control. In groups 3 and 5 there is no noticeable difference in the activities of enzymes compared to group 1 ( $\mathrm{p}>0.05)$.

\section{Histopathological modifications}

Liver morphology in control and LVME (at various doses) treated groups is shown (fig. 1).

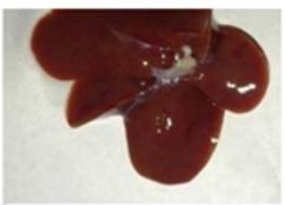

Control

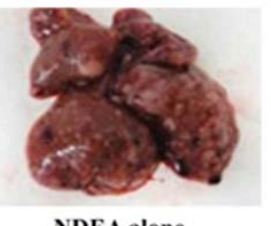

NDEA alone

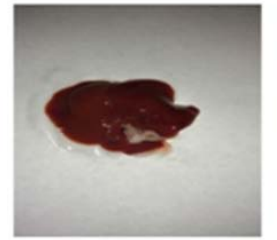

$\mathrm{NDEA}+100 \mathrm{mg} / \mathrm{kg}$ b.w.

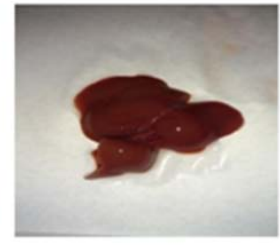

$\mathrm{NDEA}+200 \mathrm{mg} / \mathrm{kg}$ b.w.

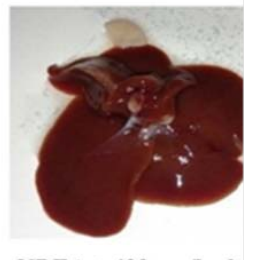

$\mathrm{NDEA}+400 \mathrm{mg} / \mathrm{kg} \mathrm{b}$

Fig. 1: A. Normal liver tissue morphology in control, B. NDEA only treated group showing HCC, C. NDEA+100 mg Lobophora variegata methanolic extract (LVME), D. NDEA+200 mg of LVME showing improvement of HCC. E. NDEA+400 mg of LVME
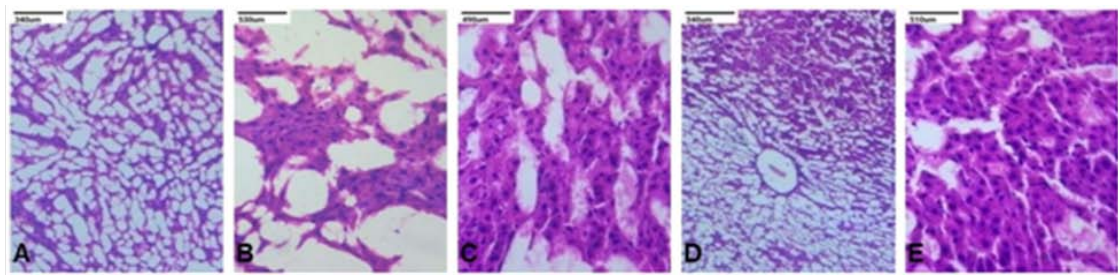

Fig. 2: Histopathological observation in the liver tissues of control rats and experimental rats. (A)Liver tissue from the normal group (control) showed hepatic lobules with normal architecture.(B) NDEA alone treated rats showed loss of architecture, mitotic, granular cytoplasm and neoplastic cells. (C) Liver tissue of the LVME $(100 \mathrm{mg} / \mathrm{kg}$ b.w.) treated rats showed loss of architecture, mitotic, granular cytoplasm and neoplastic cells. (D) A small number of neoplastically transformed cells and hepatocytes maintaining near normal architecture were observed in LVME (200

$\mathrm{mg} / \mathrm{kg}$ b.w.) treated rats. (E) LVME (400 mg/ kg b.w.) treated rats showed loss of architecture, mitotic, granular cytoplasm and neoplastic cells

The histological investigations (fig. 2) corroborate the results of serum liver/disease marker enzyme levels. Fig. 2A illustrates the normal cellular structure (group 1) and cytoplasm of hepatocytes displaying granulated cytoplasm, a central vein, small even-size nuclei and nucleoli. NDEA treatment (fig. 2B) caused the loss of normal architecture and the form of tumor cells which were smaller than normal cells and exhibit granular cytoplasm with large hyperchromatic nuclei, NDEA treated animals (group 3) were treated with LVME $(100 \mathrm{mg} / \mathrm{kg}$ b.w.) displayed a failure of normal cellular architecture and a minor inclination to spread via intrahepatic veins, in hepatic as well as portal vessels (fig. 2C),

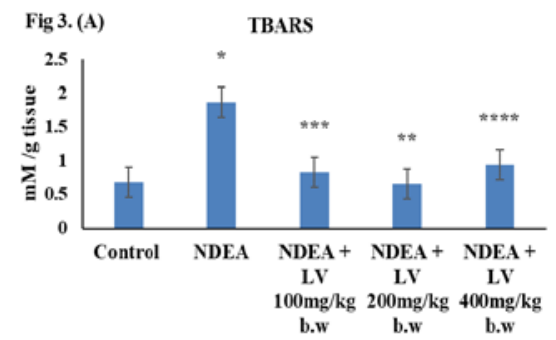

whereas NDEA with LVME (200 mg/kg b.w.) administered rats (group 4) exhibited hardly any neoplastically transformed cells, and their hepatic cells sustained a near-normal architecture (fig. 2D). NDEA treated animals administered with LVME $(400 \mathrm{mg} / \mathrm{kg}$ b.w.) (group 5) exhibit a loss of usual cellular structures and a comparably decreased inclination to spread via intrahepatic veins in the portal as well as hepatic vessels (fig. 2E).

\section{Biochemical assays}

The modulations in the concentrations of lipid peroxidation products in all groups of rats are depicted (fig. 3A).

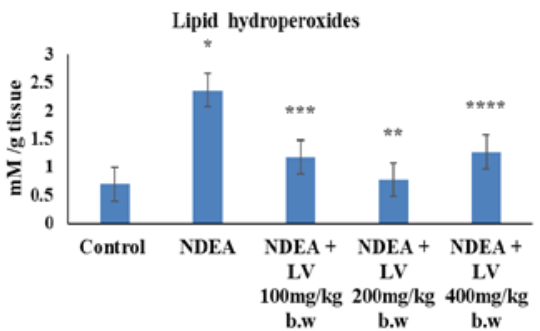

Fig. 3A: Changes in the levels of TBARS and lipid peroxidation in liver tissues of experimental rats, which are expressed in mmol per gram liver tissue. * Significantly different from control had p-value less than 0.05 , even though $* * * * *, * * * *$ significantly different from NDEA only treated group, only ** group had the higher difference when compared among them, which had p-value less than 0.05 ANOVA followed by DMRT 
In NDEA administered rats (group 2) the concentrations of TBARS and lipid hydroperoxides were noticeably elevated $(p<0.05)$ as related to control rats. Administration of LVME (group 4) noticeably decreased $(\mathrm{p}<0.05)$ the levels of TBARS and lipid hydroperoxides compared to group 2 (NDEA only). The
LMVE has a differential effect on phase I (cytochrome P450), phase II detoxication enzymes (GST), the level of GST were noticeably reduced, while the level of cytochrome P450 was elevated in liver tumor-bearing animals as related with control rats (fig. 3B).
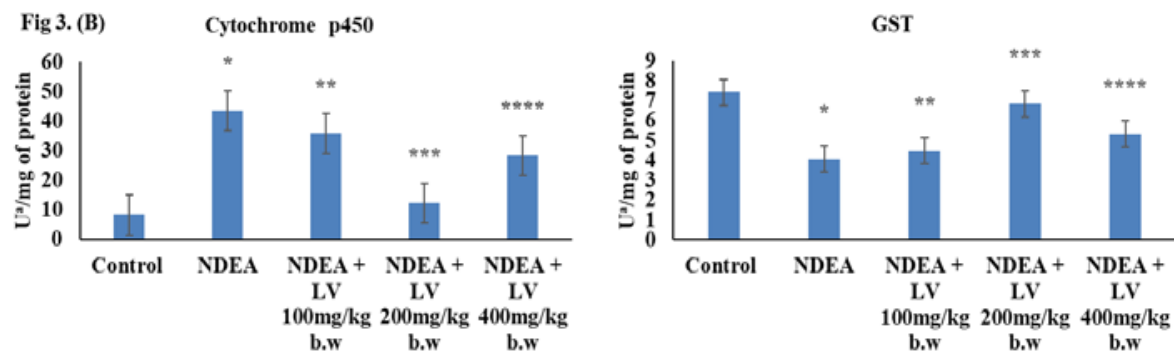

Fig. 3B: Activities of Phase I and II xenobiotic enzymes in liver of experimental and control rats. Both Cyt p450 and GST enzymes * group significantly different from their respective controls with a p value less than 0.05 . Even though the groups $* *, * * *, * * * *$ varies significantly when compared with NDEA group for both cyt p450 and GST, but only *** exhibits the higher statistically significant reduction and increase with a palue less than 0.05 for both Cyt p450 and GST enzymes, respectively
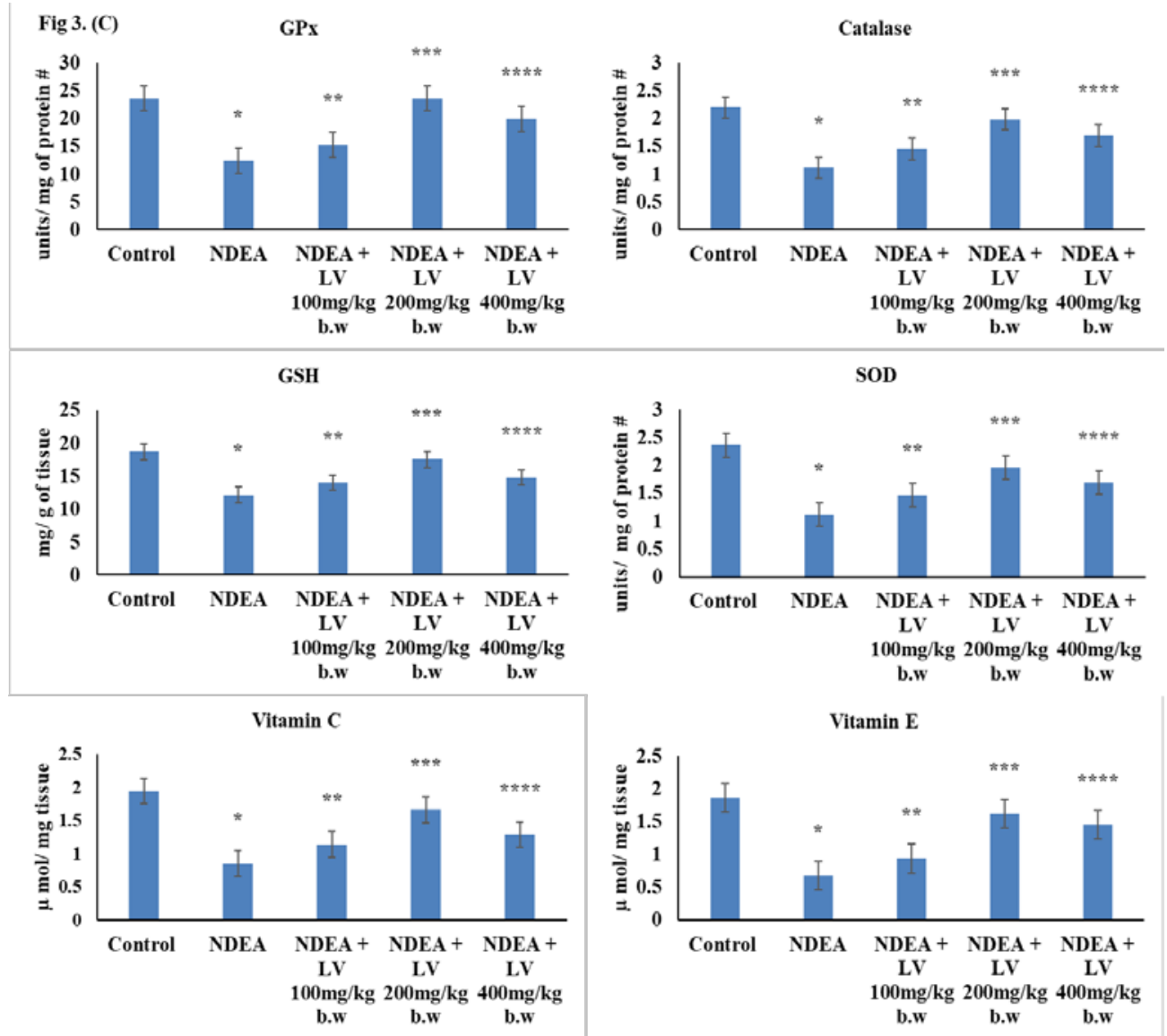

Fig. 3C: Changes in the levels of enzymatic and non-enzymatic antioxidant status in experimental rats. Here in this experiment, both enzymatic and non-enzymatic parameters follow the similar pattern. The NDEA only group * significantly varies from the control with a $p$ value less than 0.05 . Even though the groups $* *, * * *, * * *$ differs significantly when compared with NDEA only group, group *** only shows the highest recovery of antioxidant status among them with a value of less than 0.05 ANOVA followed by DMRT

Treatment of NDEA administered animals with the LMVE has noticeably reduced phase I and increased phase II enzyme activities compared to group 2 . A noticeable decrement $(p<0.05)$ in the levels of enzymatic and non-enzymatic antioxidants in (group 2) rats was noticed. Treatment with LVME had noticeably increased $(\mathrm{p}<0.05)$ the levels of antioxidants (enzymatic and non-enzymatic) in the liver as compared to group 2 rats (fig. 3C).

\section{\# Units of enzymatic activity are defined as,}

SOD, one unit of activity defined as the enzymatic reaction showing $50 \%$ inhibition of NBT reduction in one minute. Catalase, one unit defined as $\mu$ mol of hydrogen peroxide consumed per minute. For Gpx, one unit is defined as $\mu \mathrm{g}$ of glutathione consumed per minute. 


\section{DISCUSSION}

Histopathological findings in LVME treated rat liver were a nearnormal morphology with the absence of necrosis compared to the pattern with NDEA treatment alone. Our findings indicate that LVME in parenchymal cell regeneration in liver through histopathological studies, thus caring liver cell membrane and cell integrity by scavenging free radicals and promoting antioxidant status, thus diminishing enzyme leakage and hamper the progression of carcinogenesis. Numerous studies afford evidences that LVME could increase the liver/disease marker enzymes in serum during hepatotoxicity (induced by chemicals) by diminishing free radicals and lipid peroxidation and promoting antioxidants [22]. The present study suggested that LVME could protect the progression of liver cancer. In addition to the key antioxidant property, flavonoids present in $L$. variegata also exhibit several diverse biological properties that promote the health aspects in humans. These properties are, for example, antiulcer, anti-inflammatory, antiviral, antiulcer, anti-diabetic, anti-cancer, and cytoprotective, etc. [23].

There are many studies on the flavonolic contents of seaweeds [24]. Some investigations documented those seaweeds are rich source of catechins and other flavonoids. Flavonoids such as rutin, quercitin and hesperidin, among others, were detected in species of Rhodophyta, Chlorophyta and Phaeophyceae [25] and diverse bioactive phytochemicals have been identified, for instance, hesperidin, kaempferol, catechin and quercetin [26] including in $L$. variegata.

The impact of LVME on modulation on xenobiotic-metabolizing enzymes is obvious from our observation. It also increases the antioxidant status and decreases the deleterious lipid peroxidation due to NDEA ethyl radical metabolites by decreasing toxic products like malondialdehyde (MDA). The abovementioned factors play a significant role in reacting with cellular targets like DNA, thus persuading mutagenicity and carcinogenicity. The reduced activities of antioxidants (enzymatic and non-enzymatic) in NDEA-triggered hepatocellular carcinoma could be owing to over-utilization of the antioxidants to scavenge the lipid peroxidation products which ultimately leading to the distraction of antioxidant defense mechanism in hepatic tissue. Our observations corroborate the results of other studies [27].

Generally, the liver damage induced by NDEA reflects the instability of liver cell metabolism and membrane instability, subsequently leading to distinctive changes in the serum enzyme activities. Upon liver injury, liver marker enzymes (AST, ALT, and ALP) enter into the circulatory system due to the altered permeability of the membrane [28]. It correlates with our results, which showed increased activities of the enzymes in the serum of HCC induced animals. Serum LDH, a cytoplasmic marker enzyme and GGT, a membrane-bound enzyme are other well-known indicators of liver damage during various physiological and pathological conditions such as hepatocarcinogenesis [29]. The increased activities of AST, ALT, ALP and LDH observed in the present study are indicators for NDEA-induced liver damage and HCC.

Treatment with LVME inhibited NDEA induced hepatocarcinogenesis, as revealed by the diminished activities of AST, ALT, ALP and LDH. Our findings further indicate that LVME aids in parenchymal cell regeneration in liver, thus defending liver cell and membrane integrity by scavenging free radicals and promoting antioxidant status, thereby diminishing enzyme leakage and inhibit the process of carcinogenesis. Several studies provide evidence that seaweed extracts could reduce the liver marker enzymes in serum during chemically-induced hepatotoxicity by constraining free radicals and lipid peroxidation and promoting antioxidant status [30].

The LVME administration has improved the brought down the deleterious impact of NDEA-induced hepatic carcinoma by restoring the oxidant-antioxidant status also modulating the xenobiotic metabolizing enzymes, also diminishing the hepatic marker enzymes, and our observations corroborate the results of other chemoprotective agents [31]. The active ethyl radical components like O6-ethyldeoxyguanosine and 04 and 06-ethyldeoxythymidine produced by the bio transforming activity of cytochrome p450 on
NDEA is responsible for the carcinogenesis [32]. These active ethyl radical metabolites of NDEA produced by cytochrome p450could be detoxified by enzymes like GST, leading to increased cytochrome p450 and decreased GST levels as we have reported in our study. Our results provide evidences that the administration of LVME has significant role in the modulation of phase I enzyme cytochrome p450 and phase II enzyme GST by decreasing and increasing them, respectively, in the prevention of NDEA-triggered hepatocarcinogenesis. This finding is also attributing the fact that compounds of nature are good chemoprotective agents with high efficiency [33].

LVME inhibits lipid peroxidation and synthesis of free radicals by promoting antioxidant status as observed by the augmented levels of SOD, catalase and GPx and non-enzymatic antioxidants, such as vitamin E and C, and GSH. LVME was reported to possess rich levels of flavonoids, alkaloids, phenolics, tannins, glycosides, saponins, terpenoids, anthraquinones etc [34] and natural phytochemicals are found to have significant antioxidant properties as cited by various sources. Our results suggest that the modulation of the subtle balance between oxidant and antioxidants by numerous natural phytochemicals in LVME is a rational approach to prevent tumour progression. Antioxidant activities of LVME have also demonstrated in cadmium-induced liver toxicity and MNNG-induced gastric carcinogens [35].

Treatment with LVME efficiently repressed the NDEA-initiated hepatocarcinomas and its preneoplastic lesions by normalizing xenobiotic-metabolizing enzymes (XMEs) and weakened lipid peroxidation through scavenging of free radicals and promoting antioxidant status and normalizing liver/disease marker enzymes and this could be an effective step in the prevention of hepatocellular carcinoma in Wistar rats. Further investigations are in progress in our lab to elucidate the chemopreventive influences of LVME on molecular mechanisms such as apoptosis, cell proliferation, metastasis, invasion and angiogenesis during NDEA-stimulated hepatocellular HCC. Among the three doses of LVME selected in the present study, $200 \mathrm{mg} / \mathrm{kg}$ b.w. was found to be the most effective dose. The higher dose of LVME could not be effective since, a saturation point might have been reached in quenching the free radicals or other beneficial effects and the dose lower than $200 \mathrm{mg} / \mathrm{kg}$ b.w. could not also be effective as they are below the optimum dose required to exhibit the above-mentioned pharmacological effects.

\section{ACKNOWLEDGEMENT}

Funding was sanctioned by the Institute, Department of Biochemistry and Biotechnology, Faculty of Science, Annamalai University, Chidambaram, Tamil Nadu, India.

\section{FUNDING}

Nil

\section{AUTHORS CONTRIBUTIONS}

All the authors have contributed equally.

\section{CONFLICT OF INTERESTS}

\section{Declares none}

\section{REFERENCES}

1. Bray F, Ferlay J, Soerjomataram I, Siegel RL, Torre LA, Jemal A. Global cancer statistics 2018: GLOBOCAN estimates of incidence and mortality worldwide for 36 cancers in 185 countries. CA Cancer J Clin. 2018;68(6):394-424. doi: 10.3322/caac.21492, PMID 30207593.

2. Ding J, Wang $H$. Multiple interactive factors in hepatocarcinogenesis. Cancer Lett. 2014;346(1):17-23. doi: 10.1016/j.canlet.2013.12.024, PMID 24374016.

3. Balamurugan K, Karthikeyan J. Evaluation of luteolin in the prevention of N-nitrosodiethylamine-induced hepatocellular carcinoma using animal model system. Indian J Clin Biochem. 2012;27(2):157-63. doi: 10.1007/s12291-011-0166-7, PMID 23543260 .

4. Aiub CAF, Pinto LF, Felzenszwalb I. N-nitrosodiethylamine mutagenicity at low concentrations. Toxicol Lett. 
2003;145(1):36-45. doi: 10.1016/s0378-4274(03)00263-7, PMID 12962972.

5. Choi SY, Chung MJ, Sung NJ. Volatile N-nitrosamine inhibition after intake Korean green tea and maesil (Prunus mume SIEB. et ZACC.) extracts with an amine-rich diet in subjects ingesting nitrate. Food Chem Toxicol. 2002;40(7):949-57. doi: 10.1016/s0278-6915(02)00025-x, PMID 12065217.

6. Lijinsky W. N-nitroso compounds in the diet. Mutat Res. 1999;443(1-2):129-38. doi: 10.1016/s1383-5742(99)00015-0, PMID 10415436.

7. Panday S, Talreja R, Kavdia M. The role of glutathione and glutathione peroxidase in regulating cellular level of reactive oxygen and nitrogen species. Microvasc Res. 2020;131:104010. doi: 10.1016/j.mvr.2020.104010, PMID 32335268.

8. Farber JL, Gerson RJ. Mechanisms of cell injury with hepatotoxic chemicals. Pharmacol Rev. 1984;36(2);Suppl:71S5S. PMID 6382357.

9. Gey KF. Prospects for the prevention of free radical disease, regarding cancer and cardiovascular disease. Br Med Bull. 1993;49(3):679-99. 10.1093/oxfordjournals.bmb.a072640, PMID 8221032.

10. Arul D, Subramanian P. Inhibitory effect of naringenin (citrus flavonone) on $\mathrm{N}$-nitrosodiethylamine induced hepatocarcinogenesis in rats. Biochem Biophys Res Commun. 2013;434(2):203-9. doi: 10.1016/j.bbrc.2013.03.039, PMID 23523793.

11. Amado NG, Cerqueira DM, Menezes FS, da Silva JF, Neto VM, Abreu JG. Isoquercitrin isolated from Hyptis fasciculata reduces glioblastoma cell proliferation and changes beta-catenin cellular localization. Anticancer Drugs. 2009;20(7):543-52. doi: 10.1097/CAD.0b013e32832d1149. PMID 19491660.

12. Fricke A, Titlyanova TV, Nugues MM, Bischof K. Depth-related variation in epiphytic communities growing on the brown alga Lobophora variegata in a Caribbean coral reef. Coral Reefs. 2011;30(4):967-73. doi: 10.1007/s00338-011-0772-0.

13. Li Y, Wijesekara I, Li Y, Kim S. Phlorotannins as bioactive agents from brown algae. Process Biochem. 2011;46(12):2219-24. doi: 10.1016/j.procbio.2011.09.015.

14. Erdmann K, Cheung BWY, Schroder $\mathrm{H}$. The possible roles of food-derived bioactive peptides in reducing the risk of cardiovascular disease. J Nutr Biochem. 2008;19(10):643-54. doi: 10.1016/j.jnutbio.2007.11.010, PMID 18495464.

15. Sen S, Chakraborty R, Sridhar C. Free radicals, antioxidants, diseases and photomedicines: current status and future prospect. Int J Pharm Sci Rev Res. 2010;3(1):91-100.

16. Mittler R. Oxidative stress, antioxidants and stress tolerance. Trends Plant Sci. 2002;7(9):405-10. doi: 10.1016/s13601385(02)02312-9, PMID 12234732.

17. Reitman S, Frankel S. A colorimetric method for the determination of serum glutamic oxalacetic and glutamic pyruvic transaminases. Am J Clin Pathol. 1957;28(1):56-63. doi: 10.1093/ajcp/28.1.56, PMID 13458125.

18. Niehaus WG, Samuelsson B. Formation of malonaldehyde from phospholipid arachidonate during microsomal lipid peroxidation. Eur J Biochem. 1968;6(1):126-30. doi: 10.1111/j.1432-1033.1968.tb00428.x, PMID 4387188.

19. Ellman GL. Tissue sulfhydryl groups. Arch Biochem Biophys. 1959;82(1):70-7. doi: 10.1016/0003-9861(59)90090-6, PMID 13650640.

20. Rotruck JT, Pope AL, Ganther HE, Swanson AB, Hafeman DG, Hoekstra WG. Selenium: biochemical role as a component of glutathione peroxidase. Science. 1973;179(4073):588-90. doi: 10.1126/science.179.4073.588, PMID 4686466.
21. Habig WH, Pabst MJ, Hebbar G, Ziegler TR. Nutritional interventions for cancer-induced cachexia. Curr Probl Cancer. 1974;35:58-90.

22. Bagchi D, Swaroop A, Preuss HG, Bagchi M. Free radical scavenging, antioxidant and cancer chemoprevention by grape seed pro anthocyanidin: an overview. Mutation Research/Fundamental and Molecular Mechanisms of Mutagenesis. 2014;768:69-73. doi: 10.1016/j.mrfmmm.2014.04.004.

23. Vessal M, Hemmati M, Vasei M. Antidiabetic effects of quercetin in streptozocin-induced diabetic rats. Comp Biochem Physiol C Toxicol Pharmacol. 2003;135C(3):357-64. doi: 10.1016/s15320456(03)00140-6, PMID 12927910.

24. Freile Pelegrin Y, Tasdemir D. Seaweeds to the rescue of forgotten diseases: a review. Bot Marina. 2019;62(3):211-26. doi: 10.1515/bot-2018-0071.

25. Santos SAO, Felix R, Pais ACS, Rocha SM, Silvestre AJD. The quest for phenolic compounds from macroalgae: a review of extraction and identification methodologies. Biomolecules. 2019;9(12):847. doi: 10.3390/biom9120847, PMID 31835386.

26. Stark YY, Hsieh Y. Distribution of flavonoids and related compounds from seaweeds in Japan. J Tokyo Univ Fish. 2003;89:1-6.

27. Hashim Z, Ilyas A, Zarina S. Therapeutic effect of hydrogen peroxide via altered expression of glutathione S-transferase and peroxiredoxin-2 in hepatocellular carcinoma. Hepatobiliary Pancreat Dis Int. 2020;19(3):258-65. doi: 10.1016/j.hbpd.2020.03.006, PMID 32284258.

28. Singh BN, Singh BR, Sarma BK, Singh HB. Potential chemoprevention of N-nitrosodiethylamine-induced hepatocarcinogenesis by polyphenolics from Acacia nilotica bark. Chem Biol Interact. 2009;181(1):20-8. doi: 10.1016/j.cbi.2009.05.007, PMID 19446540.

29. Ramakrishnan G, Augustine TA, Jagan S, Vinodhkumar R, Devaki T. Effect of silymarin on N-nitrosodiethylamine induced hepatocarcinogenesis in rats. Experimental Oncology. 2007;29(1):39-44. PMID 17431387.

30. Lee MH, Yoon S, Moon JO. The flavonoid naringenin inhibits dimethylnitrosamine-induced liver damage in rats. Biological and Pharmaceutical Bulletin. 2004;27(1):72-6. doi: 10.1248/bpb.27.72, PMID 14709902.

31. Casal A, Roche GM, Garcia Roche M, Navajas EA, Cassina A, Carriquiry M. Differential hepatic oxidative status in steers with divergent residual feed intake phenotype. Animal. 2020;14(1):78-85. doi: 10.1017/S1751731119001332, PMID 31218981.

32. Baker SC, Mason AS, Southgate J. Procarcinogen activation and mutational signatures model the initiation of carcinogenesis in human urothelial tissues in vitro. European Urology. 2020;78(2):143-7. doi: 10.1016/j.eururo.2020.03.049, PMID 32349929.

33. Victorelli FD, Cardoso VMdO, Ferreira NN, Calixto GMF, Fontana CR, Baltazar F, Gremiao MPD, Chorilli M. Chick embryo chorioallantoic membrane as a suitable in vivo model to evaluate drug delivery systems for cancer treatment: A review. Eur J Pharm Biopharm. 2020;153:273-84. doi: 10.1016/j.ejpb.2020.06.010.

34. Meenakshi S, Gnanambigai MD, Tamil Mozhi S, Arumugam M, Balasubrmaninam $\mathrm{T}$. Total flavonoid and in vitro antioxidant activity of two seaweeds of rameshwaram coast. Global J Pharmacol. 2009;3:59-62.

35. Renugadevi J, Prabu SM. Cadmium-induced hepatotoxicity in rats and the protective effect of naringenin. Experimental Toxicologic Pathology. 2010;62(2):171-81. doi: 10.1016/j.etp.2009.03.010, PMID 19409769. 